\title{
An Analysis of the Perception of Floodplain Resident's to the Risk of Flooding in Lafia Local Government Area, Nasarawa State. Nigeria
}

\author{
Funmilayo Alfa Yusufu
}

\begin{abstract}
Flooding has become a serious environmental menace in Nasarawa State. Questionnaire was used to collect data on flood hazard, perception, adjustments and damage assessment from the residents of 15 flood-prone areas in Lafia local government area. Findings show that the population has knowledge of the hazard before moving to the study area. For the majority of the respondents, the flood hazard is either of little significance or insufficient enough to force them to consider alternative abode due to the population's cultural antecedents, that is their attachment to their native land. Also, majority of the flood victims do not get compensation or relief, and flood victims also have little or no idea of possible sources of help during flood disasters. Apart from this, they have limited knowledge of the range of adjustments and therefore lose several valuables to flooding. Majority of the population in the study area are not aware of flood alleviation measures by government, or any agency.
\end{abstract}

Keywords -Flooding, Floodplain, perception, Resident.

\section{INTRODUCTION}

\section{A. Study Area}

Lafia is both the capital of Nasarawa State and headquarters of Lafia Local Government Area. The region has a land area of $2,797.5 \mathrm{sq} . \mathrm{km}$ with a population of three hundred and thirty thousand, seven hundred and twelve people (NPC, 2007 FGN Official Gazette). Lafia is located between latitudes $8^{\circ} 20^{\prime} \mathrm{N}$ and $8^{0} 38^{\prime} \mathrm{N}$ and between longitudes $8^{0} 20^{\prime} \mathrm{E}$ and $8^{0} 40^{\prime} \mathrm{E}$. Lafia town site is on the edge of a low plateau extending eastward and northward. The steepest slopes of about $8^{0}-15^{0}$ are found in the south western part dipping northward and in the northern part. The slopes on the Lafia plateau are gentle (Offodile, 1991).

In the ordinary hydrologic literature, a flood is referred to as any relatively high flow that over-tops the natural or artificial banks in any reach of stream (Chow, 1964). It is also regarded as an over flow or inundation that comes from a river or other body of water and causes or threatens damage (Alli, 1979). In Nigeria, the hydrological changes associated with urbanization have received numerous attentions (Akintola, 1994; Ojo 1991). Various factors, including topographical conditions, rainfall characteristics and land use have been adduced as the major causes of flooding in our cities (Ologunorisa, 2001). The human factors especially increase in paved area; refuse disposal habit and occupation of the flood plain were

Funmilayo Alfa Yusufu College of Education Akwanga, Nasarawa State. Nigeriauthor emphasized by Oriola (1994) while Babatolu (1997) and Gobo (1991) emphasized the role of rainfall amount and intensity.

Flooding became a serious environmental menace when Nasarawa State was created in 1996 and Lafia was made the state capital. Lafia witnessed the influx of people to the town which has led to the indiscriminate building of structures in places within the natural courses of river. It is a known fact that as the urban population expands; new industrial and housing development also increase with inadequate urban infrastructure such as drainages and roads. Flooding was particularly severe in 1996, 1998, 1999, 2002, 2004, 2006, 2008 and 2012, forcing thousands of people to seek shelter at higher elevations and leaving farm crops and houses destroyed. Direct losses from flooding include large areas of valuable land which cannot be cultivated and the destruction of infrastructure and housing (NBS Documentary Lafia, 2013). The effects of extreme rains and floods in urban environment are often broad, devastating and costly. Over the years, Lafia has been experiencing serious drainage problem during the rainy season which may not be unconnected with the recent development attributed to the increase in the number of inhabitants in the town. Some areas in Lafia town were reserved for forest; agriculture and wild life park which were found not fit for residential areas but are now fully developed as residential areas.

Flooding has thus become an annual occurring event in Lafia town especially after heavy rainstorms. The problem is further worsened by the nature of the topography of the area, which is a low-lying plain, and the poor inadequate drainage network. Lafia lies in the low land area of the Benue trough which makes it more prone or vulnerable to flooding. Consequently, most residents in Lafia are rendered homeless (NBS Documentary, 2013). At present, there is dearth of data on the perception of the Lafia flood dwellers to the risk of flooding which will help policy planners in the development of the floodplain and in reducing the large scale damage and losses that may arise from flooding in Lafia.

\section{THE RESEARCH METHODS}

\section{A. Method of Data Collection}

Data used for this study include information on flood perception, hazard, adjustments and the level of damage, and other socio-economic losses suffered during floods. This was collected directly from the field using the questionnaire from 
the residents of Lafia in the following flood-prone areas shown in table I and their coordinates in figure 1.

TABLE I

LIST OF FLOOD PRONE AREAS

\begin{tabular}{|c|}
\hline Flood prone areas \\
\hline Tudun - Kauri \\
\hline Sabon Pegi \\
\hline GSM village \\
\hline Emir's Palace \\
\hline River Amba and its banks. \\
\hline Angwan Kutare \\
\hline Angwan Jabba \\
\hline Awe Street \\
\hline Lubona Junction \\
\hline Tudun Gwandara \\
\hline Tudun Gwandara \\
\hline Bukan Sidi \\
\hline Shendam Road, \\
\hline Shinge Road, \\
\hline Rice Mill Area \\
\hline UAC Area and \\
\hline Kilima \\
\hline
\end{tabular}

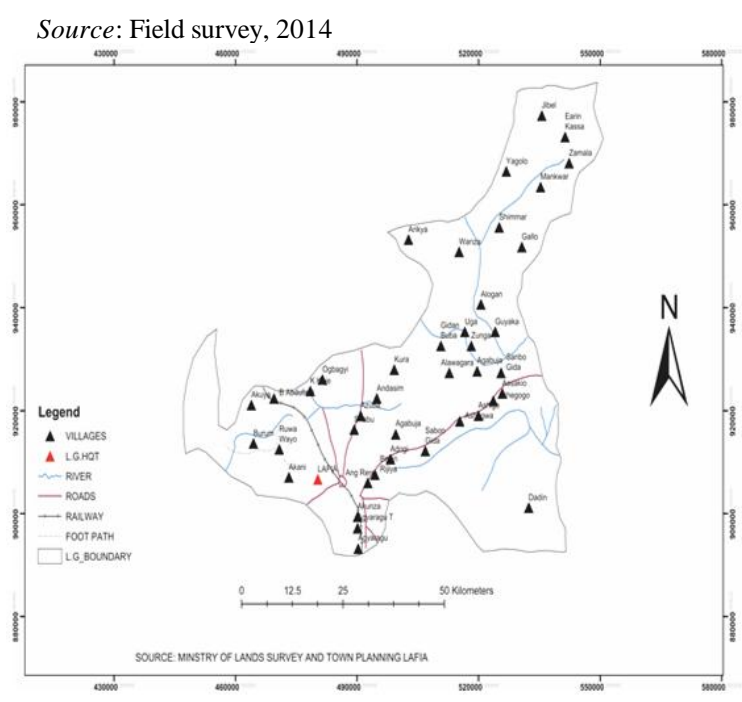

Fig 1: Study Area Showing The Flood Prone Areas.

In each of the selected locations questionnaires were distributed among the landlords using systematic random sampling technique, due to the large size of the study area and for effective coverage. Sampling of buildings depends on the population of the buildings in each settlement. However, for the purpose of this study the sampling interval for Household was 25. A total of 300 copies of questionnaires were administered to 300 flood plain residents in the study area which has a population of 330, 712(2007 FGN Official Gazzette No. 24, vol.94). This represents about $10 \%$ of the population. Questions were asked on the biodata of the head of household, his perception of the flood hazard prior to moving to the selected location in the study area; and at the time of interview, the nature of adjustment made either in anticipation of floods or during floods and reasons why the household continues to remain in the study area despite perceived flood risks. Heads of households were asked a series of questions relating to flood magnitudes and frequency, the causes of flooding, and the risk of future floods in order to gain an insight to their level of perception. They were also asked whether they are aware of any flood alleviation schemes undertaken or planned both by the landlords or the community, and on the nature of adjustments made by the heads of household with respect to evacuation during floods, and the nature and types of assistance received. The extent of the respondent's mental adjustment to the perceived flood risk was assessed by asking whether they had ever considered moving to another area because of the floods.

\section{B. Residents' Perception of Flood Hazard in Lafia}

In order to assess the perceptual level of flood among the dwellers in Lafia, structured questions aimed at elucidating required information were administered.

TABLE II

SOCIO-DEMOGRAPHIC CHARACTERISTICS OF SAMPLE POPULATION

\begin{tabular}{|c|c|c|c|}
\hline Variables & Categories & Frequency & Percentage \\
\hline \multirow[t]{2}{*}{ Sex } & Male & 201 & 67 \\
\hline & Female & 97 & 33 \\
\hline \multirow[t]{6}{*}{ Age } & $18-24$ years & 47 & 16 \\
\hline & $25-29$ years & 24 & 8 \\
\hline & $30-34$ years & 31 & 10 \\
\hline & $35-39$ years & 57 & 19 \\
\hline & $40-45$ years & 76 & 26 \\
\hline & Above 45 & 63 & 21 \\
\hline \multirow[t]{4}{*}{ Marital Status } & Single & 68 & 21 \\
\hline & Married & 212 & 71 \\
\hline & Widow/widower & 15 & 5 \\
\hline & Divorced & 3 & 1 \\
\hline \multirow[t]{6}{*}{ Occupation } & Farmer & 89 & 30 \\
\hline & Artisan & 76 & 26 \\
\hline & Retired & 12 & 4 \\
\hline & Unemployed & 16 & 5 \\
\hline & Civil Servant & 69 & 23 \\
\hline & Student & 36 & 12 \\
\hline \multirow[t]{4}{*}{ Educational Status } & Non-Formal & 6 & 12 \\
\hline & Primary & 184 & 62 \\
\hline & Secondary & 64 & 21 \\
\hline & Tertiary & 44 & 15 \\
\hline \multirow[t]{3}{*}{ Tenure of Land } & Owner & 214 & 72 \\
\hline & Tenant & 49 & 16 \\
\hline & Communal & 35 & 12 \\
\hline
\end{tabular}

Source: Field Survey, 2014

Results from analysis of socio-demographic characteristics presented in table II shows that $67 \%$ of the respondents are Males while $33 \%$ are Females. Results shows that $30 \%$ are Farmers, 26\% are Artisans, while other percentage represents other occupation categories. Also about respondents' education, $12 \%$ had no formal education, $62 \%$ had Primary, $21 \%$ had Secondary and $15 \%$ had Tertiary Education. In terms of tenure of Lands, $72 \%$ are owners of the property they occupied, $16 \%$ are tenants while $12 \%$ have communal ownership. 
TABLE III

DURATION OF STAY IN LAFIA AREA

\begin{tabular}{|l|l|l|l|}
\hline \multicolumn{1}{|c|}{ Variables } & Categories & Frequency & Percentages \\
\hline \multirow{5}{*}{ Duration of Stay in area } & Less than 1 year & 4 & 1 \\
\cline { 2 - 4 } & $1-3$ years & 31 & 10 \\
\cline { 2 - 4 } & $4-6$ years & 33 & 11 \\
\cline { 2 - 4 } & $7-9$ years & 113 & 38 \\
\cline { 2 - 4 } & $10-12$ years & 56 & 19 \\
\cline { 2 - 4 } & Above 12 years & 61 & 20 \\
\hline & &
\end{tabular}

Source: Field Survey, 2014

Table 3 shows that $20 \%$ of the respondents has lived in the area for over 12 years and $38 \%$ of the respondents have lived in the area between 7 to 9 years; period which shows some high degree of stability.

Questions were also asked if the respondents had ever experienced flooding in the locality, about $97 \%$ of the respondents have experienced flooding in the area they were interviewed. This question was asked in order to ensure that those interviewed had experience flooding in their area, so that we can have valid information on the perception sought for in the study.

TABLE IV

CAUSES OF FLOODING IN LAFIA

\begin{tabular}{|l|l|l|l|}
\hline Variables & Categories & Frequency & Percentages \\
\hline \multirow{4}{*}{ Cause of Flooding } & Don't Know & 21 & 7 \\
\cline { 2 - 4 } & Will of God & 12 & 4 \\
\cline { 2 - 4 } & Heavy or continuous Rain & 69 & 23 \\
& & & \\
\cline { 2 - 4 } & River Overflow & 73 & 24 \\
\cline { 2 - 4 } & Absence of Drainage & 84 & 28 \\
& & & 3 \\
\hline & Poor Location & 8 & 10 \\
\hline & Blocked Drainage & 31 & \\
\hline
\end{tabular}

Source: Field Survey, 2014

Opinion regarding the causes of Flooding indicates fairly wide variations in the respondents' perception of the nature of the hazard; Table 4 shows that $28 \%$ of the respondents recognized absence of Drainage as the major cause of Flooding, followed by River Overflow (24\%). Others also see heavy or continuous Rain $(23 \%)$ and Blockage of Drainage $(10 \%)$ as the cause of flooding in Lafia and about $4 \%$ of the respondents believe that flooding is caused by the "Will of God".

In terms of time taken for flood to last, result shows that $62 \%$ of the respondents indicate that flood last for less than 4 hours in the area and $31 \%$ indicate that flood last for about 5 to 9 hours in the area and $7 \%$ shows no response. And about the frequency, result shows $58 \%$ of the respondents indicate that flooding occurs about 0 to 4 times in a month and $27 \%$ of the respondents indicate that flooding occurs about 5 to 9 times in a month in the afternoon and early morning especially 12.00 to $3.00 \mathrm{pm}$; and 5.00am to 9.00am local time.

Also about $97 \%$ of the respondents evacuated their homes or Offices as soon as flooding events set in, while only about $3 \%$ do not really bother to evacuate their homes and Offices because of Flooding problems. In fact about $75 \%$ spends between 3-4 days outside their homes and Offices during Flood problems.

TABLE V

LOSS OF VALUABLE TO FLOODING

\begin{tabular}{|c|l|l|l|}
\hline Variables & Categories & Frequency & Percentages \\
\hline $\begin{array}{c}\text { Loss Valuables to } \\
\text { Flooding }\end{array}$ & Yes & 210 & 70 \\
\hline & No & 88 & 30 \\
\hline
\end{tabular}

Source: Field Survey, 2014
In terms of loss of valuable to flooding, about $70 \%$ of the respondents have lost their valuable to flooding in the area of study. This indicate the extent to which flooding is a problem in this area (see Table 5).

When asked to list valuables lost to flooding, $31 \%$ of the respondents indicated Electronics followed by clothing (30\%) and Farm land produce (28\%) and about $12 \%$ of the respondents indicated loss of lives.

$$
\text { TABLE V }
$$

AWARENESS OF FLOOD ALLEVIATION SCHEMES

\begin{tabular}{|l|l|l|l|}
\hline Variables & Categories & Frequency & Percentages \\
\hline Aware of Flood Allaviation Schemes & Yes & 212 & 71 \\
\hline Nature of Allaviation Measure & No & 86 & 29 \\
\hline & Construction of drainage & 142 & 48 \\
\hline & Clearing drainage & 98 & 33 \\
\hline & $\begin{array}{l}\text { Alternative } \\
\text { Accommodation }\end{array}$ & 58 & 19 \\
\hline
\end{tabular}

Source: Field Survey, 2014

On the knowledge of flooding alleviation schemes, the above Table 5 shows that $71 \%$ of the respondents indicated their knowledge and only about $29 \%$ had no knowledge of any flood alleviation schemes. About the nature of the alleviation measures, $48 \%$ of the respondents indicated construction of drainages, 33\% indicated clearing of drainages and 19\% indicated provision of alternative accommodation.

\section{CONCLUSION AND RECOMMENDATIONS}

Majority of flood plain residents have stayed in the area for a considerate period of 12 years and above, the population has knowledge of the hazard before moving to the study area. It would rather seem that for the majority of the respondents, the flood hazard is either of little significance or insufficient enough to force them to consider alternative abode due to the population's cultural antecedents that is their attachment to their native land. Also, majority of the flood victims do not get compensation or relief, and flood victims also have little or no idea of possible sources of help during flood disasters. Apart from this, they have limited knowledge of the range of adjustments and therefore lose several valuables to flooding. Majority of the population in the study area are not aware of flood alleviation measures by government, or any agency.

- There is need for flood insurance schemes for residents of flood plain in Lafia as a way of reducing the loss arising from flooding in the region.

- Also, majority of the flood victims do not get compensation or relief, and flood victims also have little or no idea of possible sources of help during flood disasters. The need for government assistance at national, state and local levels is therefore solicited. Apart from this, they have limited knowledge of the range of adjustments and therefore lose several valuables to flooding. Majority of the population in the study area are not aware of flood alleviation measures by government, or any agency. Studies by Ayoade and Akintola (1980) have shown that poverty and ignorance are factors that limit adjustments to flood hazard in developing countries. 


\section{REFERENCES}

[1] F.O Akintola,.. "The Parameters of Infiltration Equations in Urban Landuse Surfaces." Unpublished Ph.D Thesis, Department of Geography, University of Ibadan, Nigeria 1994.

[2] Alli, G.. "Regional Flood Frequency Analysis for Water Resoruces Development:" A Case Study of Kano State. Unpublished M.Sc. Dissertation, Department of Geography, University of Jos, Nigeria. 1979.

[3] Ayoade, J.O. and Akintola, F.O.. 'Flood Perception in two Nigerian Cities'. Environment International, Vol. 4, pp, 227 - 280, 1980

[4] Babatolu, J.S.'The June 24th, 1995 Flood in Ondo: Its Antecedent and Incident'. Ife ResearchPublication in Geography, Vol. 6, pp. 158 - 164. 1997.

[5] Chow, V.T. Handbook of Applied Hydrology. McGraw-Hill, New York. 1964

[6] Gobo, A.E. 'The 1988 Flood in the Niger Delta': The Case of Ndoni. Journal of Meteorology, Vol. 16, No. 163. 1991

[7] National Population Commission (NPC). Federal Republic of Nigeria Official Gazette no. 24 vol. 94.2007

[8] NBS (Nasarawa Broadcasting Service Lafia) Documentary, 2013.

[9] Offodile, M. E. An Approach to Ground Water Study and Development in Nigeria. MECON, Jos. 1991.

[10] Ojo O. 'Rainfall Distribution and Flood Hazards in Lagos Metropolitan Area'. Proceeding of International Symposium on Meteorological Hazards and Development held at Lagos and Kano September 23rd -3rd October, 1989, pp. 182-189. 1991

[11] Ologunorisa, E. T. An Assessment of Flood Risk in the Niger Delta, Nigeria. Unpublished Ph.D Thesis, Department of Geography and Environmental Management, University of Port Harcourt, Port Harcourt, 303 pp. 2001

[12] Ologunorisa, E. T. Flood Risk Assessment and Management in Nigeria. Perspective from the Niger Delta. Selfers Educational Books Makurdi, Nigeria, 2006.

[13] Ologunorisa, E. T. and Adeyemo, A. Public Perception of Flood Hazard in the Niger Delta, Nigeria. The Environmentalist. Netherlands. Vol. 25, No. 1 , pp. 39 - 45.2004

[14] Oriola, O. 'Strategies for Combating Urban Flooding in Developing Countries: A Case Study from Ondo'. The Environmental Vol. 14, No. 1, pp. $57-62.1994$. 